\title{
Microbacterium insulae sp. nov., isolated from soil
}

Correspondence
Jung-Hoon Yoon
jhyoon@kribb.re.kr

\author{
Jung-Hoon Yoon, ${ }^{1}$ Peter Schumann, ${ }^{2}$ So-Jung Kang, ${ }^{1}$ Chang-Soo Lee, ${ }^{1}$ \\ Soo-Young Lee ${ }^{1}$ and Tae-Kwang $\mathrm{Oh}^{1}$
}

\author{
${ }^{1}$ Korea Research Institute of Bioscience and Biotechnology (KRIBB), PO Box 115, Yusong, Taejon, \\ Republic of Korea \\ ${ }^{2}$ DSMZ - Deutsche Sammlung von Mikroorganismen und Zellkulturen GmbH, Inhoffenstraße 7B, \\ D-38124 Braunschweig, Germany
}

\begin{abstract}
A Gram-positive, non-motile, rod- or coccoid-shaped Microbacterium-like bacterium, designated strain DS- $66^{\top}$, was isolated from soil of Dokdo, Korea, and its exact taxonomic position was investigated by using a polyphasic approach. Strain DS- $66^{\top}$ grew optimally at $30{ }^{\circ} \mathrm{C}$ and $\mathrm{pH} 6.5-$ 7.0 in the presence of $0.5-1.0 \%(\mathrm{w} / \mathrm{v}) \mathrm{NaCl}$. Phylogenetic analysis based on 16S rRNA gene sequences showed that strain DS- $66^{\top}$ belonged to the genus Microbacterium. Strain DS- $66^{\top}$ had a peptidoglycan type based on $\mathrm{B} 2 \beta$ with partial substitution of glutamic acid by 3-hydroxy glutamic acid (Glu/Hyg-Gly-D-Orn), and galactose, rhamnose and ribose as whole-cell sugars. The acyl type was glycolyl. Strain DS- $66^{\top}$ contained MK-13, MK-12 and MK-14 as predominant menaquinones and anteiso- $C_{15: 0}$, anteiso- $C_{17: 0}$, iso- $C_{17: 0}$ and iso- $C_{16: 0}$ as major fatty acids. Major polar lipids were diphosphatidylglycerol, phosphatidylglycerol, an unidentified phospholipid and an unidentified glycolipid. The DNA G + C content was 69.9 mol\%. Phylogenetic distinctiveness, DNA-DNA relatedness data and differential phenotypic properties demonstrated that strain DS- $66^{\top}$ is distinguishable from recognized Microbacterium species. On the basis of the data presented, strain DS- $66^{\top}$ is considered to represent a novel species of the genus Microbacterium, for which the name Microbacterium insulae sp. nov. is proposed. The type strain is DS-66 ${ }^{\top}\left(=\right.$ KCTC $19247^{\top}=$ CCUG $\left.54523^{\top}\right)$.
\end{abstract}

The genus Microbacterium was proposed by Orla-Jensen (1919); at the time of writing, the genus comprised 50 species with validly published names, including several described since 2006: Microbacterium koreense (Lee et al., 2006), M. paludicola (Park et al., 2006), M. aoyamense, M. deminutum and M. pumilum (Kageyama et al., 2006), M. indicum (Shivaji et al., 2007), M. sediminicola and $M$. marinilacus (Kageyama et al., 2007), M. ginsengisoli (Park et al., 2008) and M. hatanonis (Bakir et al., 2008). Here we report on the taxonomic characterization of a Microbacterium-like strain, designated DS- $66^{\mathrm{T}}$, which was isolated from soil of Dokdo, Korea.

Strain DS- $66^{\mathrm{T}}$ was isolated by using the standard dilution plating technique at $25{ }^{\circ} \mathrm{C}$ by using $10 \times$ diluted nutrient agar (Difco). The type strains of three recognized Microbacterium species were used as reference strains: Microbacterium hominis DSM $12509^{\mathrm{T}}$ and Microbacterium

The GenBank/EMBL/DDBJ accession number for the 16S rRNA gene sequence of strain DS-66 ${ }^{\top}$ is EU239498.

An extended neighbour-joining tree based on 16S rRNA gene sequences showing the phylogenetic positions of strain DS- $66^{\top}$, the type strains of Microbacterium species and representatives of some other related taxa is available as supplementary material with the online version of this paper. trichothecenolyticum DSM $8608^{\mathrm{T}}$ were obtained from the Deutsche Sammlung von Mikroorganismen und Zellkulturen (DSMZ), Braunschweig, Germany and Microbacterium xylanilyticum KCTC $19079^{\mathrm{T}}$ was obtained from the Korean Collection for Type Cultures, Taejon, Korea. The morphological, physiological and biochemical characteristics of strain DS- $66^{\mathrm{T}}$ were investigated by using routine cultivation on trypticase soy agar (TSA; Difco) at $30{ }^{\circ} \mathrm{C}$. Cell morphology was examined by using light microscopy (E600; Nikon) and transmission electron microscopy (CM-20; Philips). Flagellation was determined by using transmission electron microscopy on cells from exponentially growing cultures negatively stained with $1 \%$ (w/v) phosphotungstic acid. Grids were examined after being air-dried. The Gram reaction was determined by using the bioMérieux Gram stain kit according to the manufacturer's instructions. Growth at various temperatures $\left(4,10,15,20,25\right.$ and $28{ }^{\circ} \mathrm{C}$, and from 30 to $40{ }^{\circ} \mathrm{C}$ in $1{ }^{\circ} \mathrm{C}$ increments) was measured on TSA. To investigate tolerance to $\mathrm{NaCl}$, trypticase soy broth (TSB) was prepared according to the formula of the Difco medium and $\mathrm{NaCl}$ concentrations were varied $[0.5 \%(\mathrm{w} / \mathrm{v})$ and $1.0-7.0 \%$ $(\mathrm{w} / \mathrm{v})$ at increments of $1.0 \%]$. The $\mathrm{pH}$ range for growth was determined in nutrient broth (Difco) that was adjusted to various $\mathrm{pH}$ values $(\mathrm{pH} 4.5-10.5$ at intervals of $0.5 \mathrm{pH}$ 
units) prior to sterilization by the addition of $\mathrm{HCl}$ or $\mathrm{Na}_{2} \mathrm{CO}_{3}$. Growth under anaerobic conditions was determined after incubation in an anaerobic chamber on TSA and on TSA supplemented with potassium nitrate $(0.1 \%$, $\mathrm{w} / \mathrm{v})$. Catalase and oxidase activities and hydrolysis of casein, gelatin, hypoxanthine, starch, Tweens 20, 40, 60 and 80 , tyrosine, urea and xanthine were determined as described by Cowan \& Steel (1965). Hydrolysis of aesculin and reduction of nitrate were studied as described by Lányí (1987). Susceptibility to antibiotics was tested on TSA plates using antibiotic discs containing the following compounds: polymyxin B (100 U), streptomycin $(50 \mu \mathrm{g})$, penicillin $\mathrm{G}(20 \mathrm{U})$, chloramphenicol $(100 \mu \mathrm{g})$, ampicillin $(10 \mu \mathrm{g})$, cephalothin $(30 \mu \mathrm{g})$, gentamicin $(30 \mu \mathrm{g})$, novobiocin $(5 \mu \mathrm{g})$, tetracycline $(30 \mu \mathrm{g})$, kanamycin $(30 \mu \mathrm{g})$, lincomycin $(15 \mu \mathrm{g})$, oleandomycin $(15 \mu \mathrm{g})$, neomycin $(30 \mu \mathrm{g})$ and carbenicillin $(100 \mu \mathrm{g})$. Utilization of various substrates, enzyme activities, and other physiological and biochemical properties were tested by using the API 20E, API 20NE, API $50 \mathrm{CH}$ and API ZYM systems (bioMérieux); utilization of various substrates was determined by inoculating API 20NE and API $50 \mathrm{CH}$ strips with cells suspended in AUX medium (bioMérieux).

Cell biomass for DNA extraction and for analyses of cellwall components, isoprenoid quinones and polar lipids was obtained from cultures grown by shaking at 150 r.p.m. in TSB at $30^{\circ} \mathrm{C}$. Chromosomal DNA was isolated and purified according to the method described by Yoon et al. (1996), with the exception that RNase T1 was used in combination with RNase A to minimize contamination with RNA. The $16 \mathrm{~S}$ rRNA gene was amplified by PCR by using two universal primers as described previously (Yoon et al., 1998). Sequencing of the amplified 16S rRNA gene and phylogenetic analysis were performed as described by Yoon et al. (2003). The DNA G+C content was determined according to the method of Tamaoka \& Komagata (1984) with the modification that DNA was hydrolysed and the resultant nucleotides were analysed by reversed-phase HPLC. The presence or absence of diaminopimelic acid in the peptidoglycan was determined by using the method described by Komagata \& Suzuki (1987). Preparation of cell walls and determination of peptidoglycan structure were carried out by using methods described by Schleifer \& Kandler (1972), MacKenzie (1987) and Groth et al. (1996). Whole-cell sugars were determined as described by Komagata \& Suzuki (1987). The cell-wall acyl type was determined as described by Uchida \& Aida (1984). Isoprenoid quinones were extracted according to the method of Komagata \& Suzuki (1987) and were analysed by using reversed-phase HPLC on a YMC ODS-A $(250 \times 4.6 \mathrm{~mm})$ column. Polar lipids were extracted according to the procedures described by Minnikin et al. (1984) and were identified by two-dimensional TLC followed by spraying with appropriate detection reagents (Minnikin et al., 1984; Komagata \& Suzuki, 1987). For fatty acid methyl ester analysis, cell mass of strain DS- $66^{\mathrm{T}}$ was harvested from TSA plates after incubation for 7 days at
$30{ }^{\circ} \mathrm{C}$. The fatty acid methyl esters were extracted and prepared according to the standard protocol of the MIDI/ Hewlett Packard Microbial Identification System (Sasser, 1990). DNA-DNA hybridization was performed fluorometrically according to the method of Ezaki et al. (1989) by using photobiotin-labelled DNA probes and microdilution wells. Hybridization was performed with five replications for each sample. The highest and lowest values obtained in each sample were excluded, and the means of the remaining three values were quoted as levels of DNA-DNA relatedness.

Morphological, cultural, physiological and biochemical characteristics of strain DS- $66^{\mathrm{T}}$ are given in the species description below or are shown in Table 1. The almostcomplete 16S rRNA gene sequence of strain DS- $66^{\mathrm{T}}$ determined in the present study comprised $1447 \mathrm{nt}$, representing approximately $96 \%$ of the Escherichia coli $16 \mathrm{~S}$ rRNA gene sequence. In the phylogenetic tree based on the neighbour-joining algorithm, strain DS- $66^{\mathrm{T}}$ fell within the radiation of the cluster comprising Microbacterium species (Fig. 1; Supplementary Fig. S1 in IJSEM Online). Strain DS- $66^{\mathrm{T}}$ exhibited $16 \mathrm{~S}$ rRNA gene sequence similarity values of $98.0,98.0,97.6$ and $96.7 \%$ with respect to the type strains of $M$. hominis, $M$. trichothecenolyticum, $M$. xylanilyticum and Microbacterium halophilum, respectively.

Under the condition of total hydrolysis $(4 \mathrm{~N} \mathrm{HCl}, 16 \mathrm{~h}$ at $100{ }^{\circ} \mathrm{C}$ ), the total hydrolysate of the peptidoglycan of strain DS- $66^{\mathrm{T}}$ contained the amino acids ornithine, alanine, glycine, homoserine, glutamic acid and 3-hydroxy glutamic acid (Hyg). In addition, traces of threonine were detected. Quantitative analysis of the peptidoglycan amino acids by TLC, two-dimensional TLC and GC (Schleifer, 1985; MacKenzie, 1987; Groth et al., 1996) showed that strain DS- $66^{\mathrm{T}}$ contained alanine, glycine, threonine, homoserine, ornithine and glutamic acid at a ratio of approximately $1.5: 4.9: 0.2: 1.5: 0.6: 1.0$. The amount of 3 -hydroxy glutamic acid could not be quantified. Dinitrophenylation of the peptidoglycan revealed that D-ornithine represents the $\mathrm{N}$ terminus of the interpeptide bridge. From these data, it was concluded that strain DS- $66^{\mathrm{T}}$ has peptidoglycan type B2 $\beta$ with partial substitution of glutamic acid by 3-hydroxy glutamic acid (Glu/Hyg-Gly-D-Orn), as described by Schleifer \& Kandler (1972). The amino acids in positions 1 and 3 were glycine and L-homoserine, respectively. The acyl type of the muramic acid was glycolyl. Cell-wall sugars were galactose, rhamnose and ribose. The predominant menaquinones detected in strain DS-66 ${ }^{\mathrm{T}}$ were MK-13, MK-12 and MK-14, at a peak area ratio of approximately 64,17 and $12 \%$, respectively. Major polar lipids detected in strain DS- $66^{\mathrm{T}}$ were diphosphatidylglycerol, phosphatidylglycerol, an unidentified phospholipid and an unidentified glycolipid. Fatty acids comprising more than $0.5 \%$ of the total for strain DS- $66^{\mathrm{T}}$ were as follows: branched fatty acids anteiso- $\mathrm{C}_{15: 0}(50.3 \%)$, anteiso- $\mathrm{C}_{17: 0}(15.9 \%)$, iso- $\mathrm{C}_{17: 0}$ $(10.3 \%)$, iso- $\mathrm{C}_{16: 0}(10.2 \%)$, iso- $\mathrm{C}_{15: 0}(5.7 \%)$, iso- $\mathrm{C}_{18: 0}$ (3.7\%), anteiso- $\mathrm{C}_{19: 0}(0.8 \%)$ and iso- $\mathrm{C}_{14: 0}(0.8 \%)$; and straight-chain fatty acids $\mathrm{C}_{16: 0}(1.0 \%)$ and $\mathrm{C}_{18: 0}(0.8 \%)$. This fatty acid profile was similar to those of recognized 
Table 1. Differential phenotypic characteristics between strain DS- $66^{\top}$ and phylogenetically related Microbacterium species

Strains: 1 , DS-66 ${ }^{\mathrm{T}}$ (M. insulae sp. nov.); 2, M. hominis DSM $12509^{\mathrm{T}}$ (data from Takeuchi \& Hatano, 1998b; Kim et al., 2005 and the present study); 3, M. trichothecenolyticum DSM $8608^{\mathrm{T}}$ (Yokota et al., 1993 and the present study); 4, M. xylanilyticum KCTC $19079^{\mathrm{T}}$ (Kim et al., 2005 and the present study). +, Positive reaction; -, negative reaction; w, weakly positive reaction. All strains are positive for Gram-staining, hydrolysis of aesculin, starch and Tweens 40, 60 and 80, utilization of glycerol, L-arabinose, D-xylose, galactose, glucose, fructose, mannose, mannitol, amygdalin, aesculin, salicin, cellobiose, maltose, lactose, sucrose, trehalose, melezitose, starch, gentiobiose, turanose and gluconate, activities of leucine arylamidase and $\alpha$ glucosidase, and susceptibility to carbenicillin, cephalothin, chloramphenicol, oleandomycin, streptomycin and tetracycline. All strains are negative for production of $\mathrm{H}_{2} \mathrm{~S}$ and indole, hydrolysis of urea, utilization of erythritol, L-xylose, adonitol, sorbose, dulcitol, sorbitol, methyl $\alpha$-D-mannoside, inulin, xylitol, D-tagatose, D-fucose, Darabitol, L-arabitol, caprate and adipate, activities of arginine dihydrolase, lysine decarboxylase, ornithine decarboxylase, tryptophan deaminase, alkaline phosphatase, lipase (C14), valine arylamidase, cystine arylamidase, trypsin, $\alpha$-chymotrypsin, naphthol-AS-BIphosphohydrolase, $\beta$-glucuronidase and $\alpha$-fucosidase, and susceptibility to polymyxin $\mathrm{B}$.

\begin{tabular}{|c|c|c|c|c|}
\hline Characteristic & 1 & 2 & 3 & 4 \\
\hline Catalase & - & + & + & + \\
\hline Oxidase $^{*}$ & + & - & - & - \\
\hline Growth at $37{ }^{\circ} \mathrm{C}$ & + & + & - & + \\
\hline $\begin{array}{l}\text { Growth in } 6 \%(\mathrm{w} / \mathrm{v}) \\
\mathrm{NaCl}\end{array}$ & - & $\mathrm{w}$ & - & + \\
\hline Nitrate reduction & - & - & + & + \\
\hline \multicolumn{5}{|l|}{ Hydrolysis of:* } \\
\hline Casein & - & + & + & - \\
\hline Gelatin & + & + & + & - \\
\hline Hypoxanthine & - & - & - & + \\
\hline Tyrosine & - & - & - & + \\
\hline Tween 20 & + & + & + & - \\
\hline Xanthine & - & - & - & + \\
\hline \multicolumn{5}{|l|}{ Utilization of:* } \\
\hline D-Arabinose & - & - & - & + \\
\hline D-Ribose & - & - & - & + \\
\hline Methyl $\beta$-D-xyloside & - & - & + & - \\
\hline Rhamnose & + & + & + & - \\
\hline Inositol & - & - & + & - \\
\hline Methyl $\alpha$-D-glucoside & + & + & - & + \\
\hline$N$-Acetylglucosamine & - & + & + & + \\
\hline Arbutin & - & + & + & - \\
\hline Melibiose & - & + & + & + \\
\hline Raffinose & - & + & + & + \\
\hline Glycogen & $\mathrm{w}$ & + & + & + \\
\hline D-Lyxose & - & + & - & - \\
\hline L-Fucose & - & - & + & + \\
\hline 2-Ketogluconate & - & + & - & + \\
\hline 5-Ketogluconate & - & + & + & $\mathrm{w}$ \\
\hline Citrate & - & + & + & - \\
\hline Malate & - & + & + & + \\
\hline Phenylacetate & - & - & - & + \\
\hline
\end{tabular}

Table 1. cont.

\begin{tabular}{|c|c|c|c|c|}
\hline Characteristic & 1 & 2 & 3 & 4 \\
\hline \multicolumn{5}{|l|}{ API ZYM* } \\
\hline Esterase (C4) & $\mathrm{w}$ & + & + & - \\
\hline Esterase lipase (C8) & $\mathrm{w}$ & + & + & - \\
\hline Acid phosphatase & - & - & - & + \\
\hline$\alpha$-Galactosidase & - & + & - & + \\
\hline$\beta$-Galactosidase & - & + & $\mathrm{W}$ & $\mathrm{w}$ \\
\hline$\beta$-Glucosidase & + & + & + & - \\
\hline $\begin{array}{l}N \text {-Acetyl- } \beta \text {-glucos- } \\
\text { aminidase }\end{array}$ & + & + & + & - \\
\hline$\alpha$-Mannosidase & - & - & - & + \\
\hline \multicolumn{5}{|l|}{$\begin{array}{l}\text { Susceptibility to } \\
\text { antibiotics }\end{array}$} \\
\hline Penicillin G & + & + & - & + \\
\hline Ampicillin & + & + & - & - \\
\hline Gentamicin & - & - & - & + \\
\hline Novobiocin & + & + & + & - \\
\hline Kanamycin & - & - & - & + \\
\hline Lincomycin & + & - & - & - \\
\hline Neomycin & - & - & + & + \\
\hline Cell-wall sugars $\dagger$ & $\begin{array}{c}\text { Gal, Rha, } \\
\text { Rib }\end{array}$ & $\begin{array}{l}\text { Rha, 6dT, } \\
\text { Gal, Man }\end{array}$ & Gal, Glc & Gal, Glc \\
\hline $\begin{array}{l}\text { Amino acid at } \\
\text { position } 3\end{array}$ & $\begin{array}{l}\text { Homo- } \\
\text { serine }\end{array}$ & Lysine & $\begin{array}{r}\text { Homo- } \\
\text { serine }\end{array}$ & $\begin{array}{r}\text { Homo- } \\
\text { serine }\end{array}$ \\
\hline $\begin{array}{l}\text { Predominant } \\
\text { menaquinones }\end{array}$ & $12,13,14$ & 11,12 & 12,13 & $11,12,13$ \\
\hline $\begin{array}{l}\text { DNA G }+C \text { content } \\
(\mathrm{mol} \%)\end{array}$ & 69.9 & $71.2 \ddagger$ & 69.0 & 69.7 \\
\hline
\end{tabular}

${ }^{\star}$ Data from the present study.

$\dagger$ Gal, Galactose; Glc, glucose; Man, mannose; Rha, rhamnose; Rib, ribose; 6dT, 6-deoxytalose.

‡Value of $71.2 \mathrm{~mol} \%$ in Takeuchi \& Hatano (1998b), but $70.9 \mathrm{~mol} \%$ in Kim et al. (2005).

Microbacterium species (Takeuchi \& Hatano, 1998a, b; Kim et al., 2005; Kageyama et al., 2006; Lee et al., 2006). The DNA G $+C$ content of strain DS- $66^{\mathrm{T}}$ was $69.9 \mathrm{~mol} \%$. Based on the results of phylogenetic and chemotaxonomic investigations, it is clear that strain DS- $66^{\mathrm{T}}$ is a member of the genus Microbacterium (Takeuchi \& Hatano, 1998a, b; Kim et al., 2005; Kageyama et al., 2006; Lee et al., 2006).

Strain DS- $66^{\mathrm{T}}$ exhibited levels of DNA-DNA relatedness of $11-17 \%$ to the type strains of its three closest phylogenetic neighbours, namely M. xylanilyticum KCTC $19079^{\mathrm{T}}$ (13\%), M. hominis DSM $12509^{\mathrm{T}}(17 \%)$ and M. trichothecenolyticum DSM $8608^{\mathrm{T}}(11 \%)$. These values indicate that strain DS- $66^{\mathrm{T}}$ represents a genomic species that is distinct from M. xylanilyticum, M. hominis and $M$. trichothecenolyticum (Wayne et al., 1987). Strain DS-66 ${ }^{\mathrm{T}}$ could also be distinguished from these three recognized Microbacterium species based on differences in several phenotypic properties, as shown in Table 1. The phylogenetic distinctiveness of strain DS- $66^{\mathrm{T}}$, together with genetic distinctiveness and differential phenotypic properties, is sufficient to 


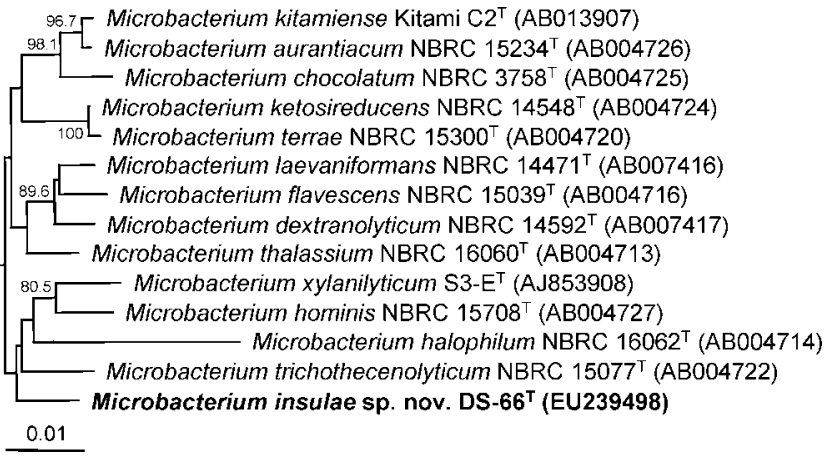

Fig. 1. Neighbour-joining phylogenetic tree based on 16S rRNA gene sequences showing the position of strain DS- $66^{\top}$ among the type strains of selected Microbacterium species. Bootstrap values (expressed as percentages of 1000 replications) are shown at branch points; only values $>50 \%$ are shown. Arthrobacter globiformis DSM 20124 ${ }^{\top}$ (GenBank accession number M23411; not shown) was used as an outgroup. Bar, 0.01 substitutions per nucleotide position. An extended phylogenetic tree from which Fig. 1 was taken is available as Supplementary Fig. S1 in IJSEM Online.

permit the allocation of this strain to a species that is separate from recognized species of the genus Microbacterium (Wayne et al., 1987; Stackebrandt \& Goebel, 1994). Therefore, on the basis of the data presented, strain DS- $66^{\mathrm{T}}$ is considered to represent a novel species of the genus Microbacterium, for which the name Microbacterium insulae sp. nov. is proposed.

\section{Description of Microbacterium insulae sp. nov.}

Microbacterium insulae (in.su'lae. L. fem. gen. n. insulae of an island, where the type strain was isolated).

Cells are Gram-positive, non-motile, non-spore-forming rods or cocci $(0.2-0.5 \times 0.5-1.8 \mu \mathrm{m})$. Colonies on TSA are circular, convex, smooth, glistening, yellow and 1.5$2.0 \mathrm{~mm}$ in diameter after 7 days incubation at $30{ }^{\circ} \mathrm{C}$. Optimal temperature for growth is $30{ }^{\circ} \mathrm{C}$. Growth occurs at 20 and $38{ }^{\circ} \mathrm{C}$, but not at 15 or $39{ }^{\circ} \mathrm{C}$. Optimal pH for growth is between 6.5 and 7.0; growth occurs at $\mathrm{pH} 5.5$ and 8.0 , but not at $\mathrm{pH} 5.0$ or 8.5. Growth occurs in the presence of $0-5.0 \%(\mathrm{w} / \mathrm{v}) \mathrm{NaCl}$ with an optimum of 0.5 $1.0 \%(\mathrm{w} / \mathrm{v})$. Anaerobic growth does not occur on TSA or on TSA supplemented with nitrate. Cell-wall peptidoglycan type is B2 $\beta$ with partial substitution of glutamic acid by 3 hydroxy glutamic acid (Glu/Hyg-Gly-D-Orn). The amino acid in position 3 of the peptidoglycan is L-homoserine. The acyl type of the muramic acid is glycolyl. Cell-wall sugars are galactose, rhamnose and ribose. Predominant menaquinones are MK-13, MK-12 and MK-14. Major fatty acids $\left(>10 \%\right.$ of the total) are anteiso- $\mathrm{C}_{15: 0}$, anteiso- $\mathrm{C}_{17: 0}$, iso- $\mathrm{C}_{17: 0}$ and iso- $\mathrm{C}_{16: 0}$. Major polar lipids are diphosphatidylglycerol, phosphatidylglycerol, an unidentified phospholipid and an unidentified glycolipid. The DNA $\mathrm{G}+\mathrm{C}$ content of the type strain is $69.9 \mathrm{~mol} \%$ (determined by HPLC). Other phenotypic characteristics are given in Table 1.

The type strain, DS-66 ${ }^{\mathrm{T}}\left(=\mathrm{KCTC} 19247^{\mathrm{T}}=\mathrm{CCUG} 54523^{\mathrm{T}}\right)$, was isolated from soil of Dokdo, Korea.

\section{Acknowledgements}

This work was supported by the 21C Frontier program of Microbial Genomics and Applications (grant MG05-0401-2-0) from the Ministry of Science and Technology (MOST) of the Republic of Korea.

\section{References}

Bakir, M. A., Kudo, T. \& Benno, Y. (2008). Microbacterium hatanonis sp. nov., isolated as a contaminant of hairspray. Int J Syst Evol Microbiol 58, 654-658.

Cowan, S. T. \& Steel, K. J. (1965). Manual for the Identification of Medical Bacteria. London: Cambridge University Press.

Ezaki, T., Hashimoto, Y. \& Yabuuchi, E. (1989). Fluorometric deoxyribonucleic acid-deoxyribonucleic acid hybridization in microdilution wells as an alternative to membrane filter hybridization in which radioisotopes are used to determine genetic relatedness among bacterial strains. Int J Syst Bacteriol 39, 224-229.

Groth, I., Schumann, P., Weiss, N., Martin, K. \& Rainey, F. A. (1996). Agrococcus jenensis gen. nov., sp. nov., a new genus of actinomycetes with diaminobutyric acid in the cell wall. Int J Syst Bacteriol 46, 234239.

Kageyama, A., Takahashi, Y. \& Ōmura, S. (2006). Microbacterium deminutum sp. nov., Microbacterium pumilum sp. nov. and Microbacterium aoyamense sp. nov. Int J Syst Evol Microbiol 56, 2113-2117.

Kageyama, A., Takahashi, Y., Matsuo, Y., Kasai, H., Shizuri, Y. \& Ōmura, S. (2007). Microbacterium sediminicola sp. nov. and Microbacterium marinilacus sp. nov., isolated from marine environments. Int J Syst Evol Microbiol 57, 2355-2359.

Kim, K. K., Park, H. Y., Park, W., Kim, I. S. \& Lee, S.-T. (2005). Microbacterium xylanilyticum sp. nov., a xylan-degrading bacterium isolated from a biofilm. Int J Syst Evol Microbiol 55, 20752079.

Komagata, K. \& Suzuki, K. (1987). Lipids and cell-wall analysis in bacterial systematics. Methods Microbiol 19, 161-207.

Lányí, B. (1987). Classical and rapid identification methods for medically important bacteria. Methods Microbiol 19, 1-67.

Lee, J.-S., Lee, K. C. \& Park, Y.-H. (2006). Microbacterium koreense sp. nov., from sea water in the South Sea of Korea. Int J Syst Evol Microbiol 56, 423-427.

MacKenzie, S. L. (1987). Gas chromatographic analysis of amino acids as the $N$-heptafluorobutyryl isobutyl esters. J Assoc Off Anal Chem 70, 151-160.

Minnikin, D. E., O'Donnell, A. G., Goodfellow, M., Alderson, G., Athalye, M., Schaal, A. \& Parlett, J. H. (1984). An integrated procedure for the extraction of bacterial isoprenoid quinones and polar lipids. J Microbiol Methods 2, 233-241.

Orla-Jensen, S. (1919). The Lactic Acid Bacteria. Copenhagen: Høst and Son.

Park, H. Y., Kim, K. K., Jin, L. \& Lee, S.-T. (2006). Microbacterium paludicola sp. nov., a novel xylanolytic bacterium isolated from swamp forest. Int J Syst Evol Microbiol 56, 535-539. 
Park, M.-J., Kim, M. K., Kim, H.-B., Im, W.-T., Yi, T.-H., Soung, N.-K. \& Yang, D.-C. (2008). Microbacterium ginsengisoli sp. nov., a $\beta$ glucosidase-producing bacterium isolated from soil of a ginseng field. Int J Syst Evol Microbiol 58, 429-433.

Sasser, M. (1990). Identification of bacteria by gas chromatography of cellular fatty acids, MIDI Technical Note 101. Newark, DE: MIDI Inc.

Schleifer, K. H. (1985). Analysis of the chemical composition and primary structure of murein. Methods Microbiol 18, 123-156.

Schleifer, K. H. \& Kandler, O. (1972). Peptidoglycan types of bacterial cell walls and their taxonomic implications. Bacteriol Rev 36, 407-477.

Shivaji, S., Bhadra, B., Rao, R. S., Chaturvedi, P., Pindi, P. K. \& Raghukumar, C. (2007). Microbacterium indicum sp. nov., isolated from a deep-sea sediment sample from the Chagos Trench, Indian Ocean. Int J Syst Evol Microbiol 57, 1819-1822.

Stackebrandt, E. \& Goebel, B. M. (1994). Taxonomic note: a place for DNA-DNA reassociation and $16 \mathrm{~S}$ rRNA sequence analysis in the present species definition in bacteriology. Int J Syst Bacteriol 44, 846849.

Takeuchi, M. \& Hatano, K. (1998a). Union of the genera Microbacterium Orla-Jensen and Aureobacterium Collins et al. in a redefined genus Microbacterium. Int J Syst Bacteriol 48, 739-747.

Takeuchi, M. \& Hatano, K. (1998b). Proposal of six new species in the genus Microbacterium and transfer of Flavobacterium marinotypicum ZoBell and Upham to the genus Microbacterium as Microbacterium maritypicum comb. nov. Int J Syst Bacteriol 48, 973-982.
Tamaoka, J. \& Komagata, K. (1984). Determination of DNA base composition by reversed-phase high-performance liquid chromatography. FEMS Microbiol Lett 25, 125-128.

Uchida, K. \& Aida, K. (1984). An improved method for the glycolate test for simple identification of the acyl type of bacterial cell walls. J Gen Appl Microbiol 30, 131-134.

Wayne, L. G., Brenner, D. J., Colwell, R. R., Grimont, P. A. D., Kandler, O., Krichevsky, M. I., Moore, L. H., Moore, W. E. C., Murray, R. G. E. \& other authors (1987). International Committee on Systematic Bacteriology. Report of the ad hoc committee on reconciliation of approaches to bacterial systematics. Int J Syst Bacteriol 37, 463-464.

Yokota, A., Takeuchi, M., Sakane, T. \& Weiss, N. (1993). Proposal of six new species in the genus Aureobacterium and transfer of Flavobacterium esteraromaticum Omelianski to the genus Aureobacterium as Aureobacterium esteraromaticum comb. nov. Int $J$ Syst Bacteriol 43, 555-564.

Yoon, J.-H., Kim, H., Kim, S.-B., Kim, H.-J., Kim, W. Y., Lee, S. T., Goodfellow, M. \& Park, Y.-H. (1996). Identification of Saccharomonospora strains by the use of genomic DNA fragments and rRNA gene probes. Int J Syst Bacteriol 46, 502-505.

Yoon, J.-H., Lee, S. T. \& Park, Y.-H. (1998). Inter- and intraspecific phylogenetic analysis of the genus Nocardioides and related taxa based on 16S rRNA gene sequences. Int J Syst Bacteriol 48, 187-194.

Yoon, J.-H., Kang, K. H. \& Park, Y.-H. (2003). Psychrobacter jeotgali sp. nov., isolated from jeotgal, a traditional Korean fermented seafood. Int J Syst Evol Microbiol 53, 449-454. 